\title{
Makna Spiritualitas pada Klien dengan Sindrom Koroner Akut
}

\author{
Aan Nur'aeni, Kusman Ibrahim, Hana Rizmadewi Agustina \\ Fakultas Keperawatan Universitas Padjadjaran \\ E-mail:an_1612@yahoo.com
}

\begin{abstract}
Abstrak
Penelitian ini dilatarbelakangi oleh tingginya angka kematian dan kecacatan di dunia akibat sindrom koroner akut (SKA). Perawatan klien dengan SKA masih terfokus pada aspek fisik, sedangkan aspek spiritualitas banyak dilupakan. Tujuan penelitian ini adalah untuk menggali secara mendalam makna spiritualitas yang dipersepsikan oleh klien dengan SKA yang menjalani perawatan di ruang intensif jantung RSUP dr. Hasan Sadikin Bandung. Untuk mencapai tujuan tersebut penelitian ini menggunakan desain deskriptif kualitatif, dengan jumlah partisipan sebanyak sepuluh orang. Pengumpulan data dilakukan dengan wawancara dan observasi. Analisis data dilakukan dengan menggunakan content analysis. Berdasarkan hasil penelitian teridentifikasi empat kategori makna spiritualitas dengan sepuluh buah tema, yaitu: (1) Spiritual adalah hubungan dengan diri sendiri dengan dua buah tema antara lain, menerima penyakit sebagai suatu teguran atau cobaan, dan hidup menjadi lebih baik; (2) Spiritual adalah hubungan dengan Tuhan dengan lima buah tema yaitu: kepasrahan pada Tuhan, ibadah atau komunikasi dengan Tuhan, harapan, permohonan ampunan (pertobatan), dan rasa syukur; (3) Spiritual adalah hubungan dengan orang lain dengan dua buah tema yaitu: perhatian, cinta, dan kasih sayang dari orang lain, serta keberhasilan keluarga, memberikan manfaat bagi sesama; dan (4) Spiritual adalah hubungan dengan alam dengan satu buah tema yaitu menyalurkan hobi atau aktivitas di alam. Berdasarkan hasil penelitian tersebut diharapkan perawat lebih sensitif terhadap makna spiritualitas klien dan mendorong penggunaan sumber spiritualitasnya untuk proses penyembuhan klien. Institusi pendidikan diharapkan mampu mempersiapkan perawat yang peka terhadap kebutuhan spiritualitas klien serta diperlukan penelitian lebih lanjut dan lebih luas dalam lingkup perawatan spiritualitas.
\end{abstract}

Kata kunci: Persepsi, spiritualitas,sindrom koroner akut.

\section{Meaning of Spirituality among Clients with acute corronary syndrome}

\begin{abstract}
This research was conducted due to the high of mortality and disability rate in the world caused by Acute Coronary Syndrome (ACS), however the treatment of ACS' clients are still focusing on physical aspects rather than spirituality aspects. Actually, these aspects are equally important. Through awareness of the meaning of spirituality, the clients can achieve spirituality comfort. Spiritual comfort can give peacefulness and positive impact to clients' health. The purpose of the study was to explore the meaning of spirituality in clients with ACS who undergone treatment in the cardiac intensive care RSHS Bandung. The study used a descriptive exploratory design with 10 participants. The data was collected through interviews and observations. The data were analysed using content analysis the data analysis performed using content analysis. The result identified four categories of the meaning of spirituality followed by 10 themes, namely : (1) Spirituality was self-relationship that consists of two themes, include a. Accepted of disease as a reproach or temptation b. Better in life; (2) Spirituality was relationship between human and God, it consists of five themes, namely : a. Self-reliance, $b$. Worship or communication with God, c. Hope, d. Asking forgiveness or repentance, e. Grateful; (3) spirituality was a relationship with others, it consists of two themes, namely : a. caring, love, affection from others, and the success of the family b. Giving to others; (4) Spirituality was relationship between human with nature, consist of one theme, namely : doing personal interest or activity in the nature environment. Based on the results, nurses are expected to be more understood to the meaning of clients' spirituality and encouraging them to use their spirituality sources for their healing process. Educational institutions are expected to prepare the student with high sensitivy of clients' spirituality needs, and then further research of spirituality care is needed with broader scopes
\end{abstract}

Key words: Acute Coronary Syndrome, perception, spirituality. 
Aan Nuraeni : Makna Spiritualitas pada Klien dengan Sindrom Koroner Aku

\section{Pendahuluan}

Penyakit jantung merupakan suatu penyebab utama kematian dan kecacatan seseorang di dunia dengan jumlah penderita yang terus mengalami peningkatan pada setiap tahunnya. Pada tahun 2008, world health organization (WHO) melaporkan terdapat sekitar 17,3 juta orang meninggal karena penyakit jantung dan jumlahnya terus meningkat pada setiap tahunnya (WHO, 2011). Penyebab kematian paling banyak di Indonesia pada tahun 2007 salah satunya adalah sindrom koroner akut (SKA) (Depkes, 2009).

Klien dengan SKA dapat jatuh ke dalam kondisi kritis ataupun kegawatdaruratan, dan ketika klien merasakan atau mengetahui mengenai kondisi sakitnya yang merupakan sakit kronis ataupun akut sehingga dapat mengancam kehidupan (life threatening disease), maka hal ini akan mengakibatkan stres pada klien. Stres yang dialami oleh klien dengan SKA dapat berakibat buruk bagi kesehatannya sehingga harus segera diatasi. Menurut Salposky dan Mott (2006) stres dapat mengakibatkan terjadinya reaksi fisiologis dalam tubuh klien antara lain yaitu dapat mengaktivasi sistem saraf simpatis dalam tubuh klien yang dapat meningkatkan denyut jantung klien, tekanan darah klien, dan frekuensi pernafasan klien. Perubahan fisiologis ini dapat menyebabkan terjadinya peningkatkan kebutuhan oksigen pada jantung klien yang sedang mengalami gangguan. Selain itu, menurut Merz, Bairey, dan Dwyer (2002) apabila stres ini terus berlangsung pada klien, hal ini dapat meningkatkan risiko terjadinya disfungsi endotelial, iskemia miokard, rupturnya plak, trombosis, dan malignant arrhytmia.

Hal lainnya yang dapat terjadi akibat stres yang berkepanjangan adalah terjadinya penurunan daya tahan tubuh klien (Zachariae, 2009). Jika klien tidak dapat segera menerima kondisi sakitnya maka akan sulit bagi klien untuk mendapatkan penyembuhan (healing) bahkan komplikasi dapat dialami oleh klien dan dapat memperburuk keadaannya.

Spiritual merupakan salah satu sumber koping individu yang dapat dilakukan oleh klien agar dapat beradaptasi dengan stresor yang dihadapi oleh klien (Puchalski, 2001). Hal ini dipertegas oleh Scott (2007) bahwa spiritualitas dapat digunakan sebagai salah satu cara yang efektif dalam menurunkan stres. Spiritual juga memiliki korelasi yang positif bagi kesehatan (Puchalski, 2001). Pada penelitian yang sama Puchalski (2001) mengungkapkan bahwa hasil penelitiannya menemukan bahwa bagi mereka yang melakukan praktik spiritualitasnya secara teraturternyata dapatmemilikikecenderungan untuk berumur lebih panjang, spiritualitas pada klien dapat digunakan sebagai sumber koping individu dalam menghadapi sakit, penyakit, dan stres, serta berkomitmen dalam spiritualitas yang cenderung meningkatkan proses penyembuhan dari suatu penyakit dan pembedahan. Beberapa penelitian juga mengindikasikan bahwa seseorang memiliki tingkat spiritualitas yang tinggi dan cenderung memperlihatkan penampilan yang positif dan kualitas hidup yang lebih baik.

Puchalski (2001) mengungkapkan lebih lanjut bahwa suatu pengobatan (cure) tidak dapat dilakukan pada setiap penyakit, akan tetapi selalu ada ruang untuk penyembuhan (healing). Proses penyembuhan adalah penerimaan terhadap suatu penyakit yang dapat menciptakan suatu ketentraman dalam kehidupan klien, dan spiritualitas dapat menjadi inti dari penyembuhan penyakit. Dalam penelitian Puchalski dkk., (2009) mengungkapkan juga bahwa penyembuhan mengacu pada kemampuan seseorang dalam mendapatkan kebahagiaan, kenyamanan, koneksi, makna, dan tujuan hidup dalam penderitaan maupun rasa sakit yang dialami oleh klien.

Makna spiritualitas padaklienmengandung arti yaitu mengungkap sesuatu yang paling berarti atau berharga dalam kehidupan klien, sehingga klien dapat lebih fokus terhadap hal-hal penting di dalam kehidupan klien. Mengungkap makna spiritualitas juga berarti mencari tahu apakah klien telah berhasil menemukan makna dan tujuan hidup pada saat sakit atau menderita. Apabila klien belum menemukan makna dan tujuan hidupnya maka menjadi tugas perawat untuk membantu klien dalam menemukan makna spiritualitasnya dan mendorong klien untuk menggunakan kekuatan spiritualitasnya tersebut sebagai energi untuk mendapatkan penyembuhan (healing) sehingga mencapai spirituality comfort atau spirituality wellbeing. 
Aan Nuraeni : Makna Spiritualitas pada Klien dengan Sindrom Koroner Akut

Penelitian Lorentz (2006) mengungkapkan pencapaian spirituality comfort atau spirituality wellbeing akan membawa klien pada ketenangan jiwa. Ketenangan jiwa dapat membawa pengaruh positif pada kesehatan klien, antara lain dapat menurunkan tingkat stres pada klien. Seiring dengan penurunan tingkat stres ini maka tubuh klien akan semakin terjaga homeostasisnya. Hal ini akan meningkatkan sistem immunitas tubuh klien dan menurunkan risiko terhadap timbulnya berbagai penyakit juga komplikasi yang tidak diharapkan pada klien.

Makna spiritualitas bagi setiap orang berbeda-beda, tergantung pada cara pandang dan latar belakang orang tersebut. Menurut Puchalski, dkk., (2009) serta Burkhardt dan Nagai-Jacobson (2005), spiritualitas ini bersifat personal atau individual. Selama ini literatur-literatur yang mengungkap makna spiritualitas sebagian besar berasal dari negara barat sedangkan kultur masyarakat Indonesia dengan negara barat sangat berbeda.

Kultur masyarakat Indonesia sangat lekat dengan religiositas terutama agama Islam, hal ini berbeda dengan kultur di negara barat yang lebih didominasi dengan paham sekularisme dan kebebasan. Sebagian besar budaya di Indonesia terdapat kepercayaan kepada kekuatan super natural yang paling tinggi yang sangat berkuasa dan menentukan segalanya yaitu Tuhan Yang Maha Esa. Hal ini mungkin saja dapat berpengaruh terhadap spiritualitas masyarakat, dan menambah hal baru berkaitan dengan konsep spiritualitas.

Pada penelitian ini peneliti bertujuan untuk melihat lebih jauh mengenai makna spiritualitas yang dialami oleh klien dengan sindrom koroner akut yang menjalani perawatan di instalasi perawatan intensif jantung di Ruang Intensif Jantung Rumah Sakit Umum Pemerintahan (RSUP) dr. Hasan Sadikin Bandung.

\section{Metode Penelitian}

Metode penelitian yang digunakan untuk mengungkapkan makna spiritualitas di penelitian ini adalah metode induktif atau kualitatif, dengan menggunakan teknik semisructured interviews. Penelitian ini dilakukan di unit perawatan jantung intensif
RSUP dr. Hasan Sadikin Bandung yaitu di ruang coronary intensive care unit (CICU).

Partisipan yang terlibat dalam penelitian ini adalah klien dengan sindrom koroner akut yang meliputi klien dengan unstable angina pectoris (UAP) maupun klien dengan infark miokard (IM) baik ST elevation miocard infark STEMI maupun non-STEMI yang sudah mengalami perbaikan dengan kondisi yang relatif stabil dan sedang menjalani perawatan di Ruang CICU RSUP dr. Hasan Sadikin Bandung yaitu sebanyak sepuluh orang. Sebagian besar partisipan beragama Islam yaitu sebanyak sembilan orang dan satu orang beragama Katolik. Sebagian besar partisipan berlatarbelakang budaya Sunda yaitu sebanyak delapan orang, partisipan lainnya berbudaya Batak dan Jawa masingmasing berjumlah satu orang. Terdapat pula partisipan lain sebagai bagian dari triangulasi data yang bertujuan untuk mengonfirmasi data yakni dari keluarga klien.

Instrumen yang digunakan dalampenelitian ini adalah peneliti sebagai instrumen utama, pedoman wawancara, pedoman observasi, dan alat perekam suara. Pengumpulan data dilakukan dengan melakukan wawancara dan observasi pada partisipan.

Wawancara dilakukan di ruang perawatan klien dengan rentang waktu 20-60 menit. Pada penelitian ini data yang terkumpul dari hasil wawancara dan catatan lapangan dianalisis dengan menggunakan content analysis yang direkomendasikan oleh Hancock (2002).

Peneliti melakukan teknik pemeriksaan yang berdasarkan atas sejumlah kriteria tertentu meliputi credibility, transferability, dependability, dan confirmability. Teknik ini digunakan untuk mendapatkan keabsahan (trustworthness) data agar hasil penelitian mempunyai keabsahan dan kekuatan ilmiah. Data yang terkumpul dari hasil wawancara dan catatan observasi dianalisis menggunakan teknik content analysis menurut Hancock (2002).

\section{Hasil Penelitian}

Partisipan dalam penelitian ini sebagian besar adalah laki-laki yaitu sebanyak enam orang, dan empat orang perempuan. Hampir seluruh partisipan berusia lebih dari 50 tahun 
Aan Nuraeni : Makna Spiritualitas pada Klien dengan Sindrom Koroner Aku

yaitu sebanyak sembilan orang dan hanya satu orang yang berusia kurang dari 50 tahun. Sebanyak sembilan orang partisipan beragama Islam dan satu orang beragama Katolik.

Partisipan diberikan pertanyaan mengenai sumber kekuatan dan kebahagiaannya saat ini, kemudian ditanyakan juga mengenai makna sakit dan hikmah sakit yang mereka persepsikan serta makna dan tujuan hidup yang mereka miliki saat ini. Berdasarkan hasil wawancara dan hasil dari analisis data yang dilakukan, makna spiritualitas pada partisipan dalam penelitian ini, meliputi empat buah kategori dan didalamnya terdiri dari sepuluh buah tema.

Kategori pertama yang didapatkan dalam penelitian yaitu mengenai spiritualitas adalah hubungan dengan diri sendiri dengan Tuhan. Pada kategori ini memuat dua buah tema yaitu menerima penyakit sebagai suatu teguran atau cobaan dan hidup menjadi lebih baik. Pada tema menerima penyakit sebagai suatu teguran atau cobaan, seluruh partisipan mengungkapkan bahwa saat ini mereka telah menerima kondisi sakit yang dialami dan mereka memaknai sakit ini sebagai teguran atau cobaan dari Tuhan. Salah seorang partisipan menyatakan

"penyakit ini memang berat.. tapi tidak ada rasa kesal mungkin ini sudah menjadi kehendak Allah, cobaan buat saya, kalau marah saat ini tidak ada, karena sudah menjadi kehendak Allah, saya menerima saja".

Pada tema hidup menjadi lebih baik, yang dimaksud oleh partisipan disini meliputi introspeksi diri yang dilakukan setelah sakit baik pada kesalahan-kesalahan atau dosa yang telah dilakukan maupun gaya hidup yang tidak sehat pada saat sebelum sakit. Berikut beberapa ungkapan partisipan mengenai hal ini:

"sekarang hikmahnya ibu jadi lebih sabar, lebih introspeksi diri dengan dosa-dosa..."

"...kebiasaan-kebiasaan buruk yang dulu seperti merokok mungkin nanti bisa berhenti, bisa diperbaiki, karena saya ingin berubah, tidak mau terulang seperti ini lagi”.

Kategori yang kedua yaitu partisipan mengungkapkan bahwa spiritualitas adalah hubungan dengan Tuhan. Hal ini memuat lima buah tema, yaitu: kepasrahan pada
Tuhan merupakan sumber kekuatan, ibadah atau komunikasi dengan Tuhan merupakan sumber kekuatan, harapan merupakan sumber kekuatan, spiritualitas adalah permohonan ampunan (pertobatan), dan rasa syukur sebagai sumber kekuatan.

Pada tema kepasrahan pada Tuhan merupakan sumber kekuatan, partisipan mempersepsikan Tuhan sebagai suatu sumber kekuatan hidup bahwa pasrah pada Tuhan-lah yang justru menguatkan mereka. Sebanyak sembilan orang partisipan mengungkapkan hal ini. Seperti yang diungkapkan oleh salah satu partisipan:

" yang membuat saya tenang saya mempasrahkan diri, pasrah sepasrahnya sama Yang Punya, Allah. Kalau Tuhan menghendaki ya kalau mau diambil ya ambillah...ga da ketenangan kalau tidak ada kepasrahan".

Pada tema ibadah atau komunikasi dengan Tuhan merupakan sumber kekuatan, beberapa partisipan mengungkapkan bahwa kekuatannya adalah dengan berkomunikasi dengan Tuhan. Berikut salah satu ungkapan dari partisipan yaitu:

"setelah curhat sama Allah rasanya agak ringan. Pada saat curhat malam-malam ibu suka nangis. Seperti ngobrol, hanya saja kalau kita ngobrol dengan manusia langsung dapat jawaban, paling sama Allah mah besok lusa, tiba-tiba ada ilham aja. Yang tadinya bingung menjadi terbuka....kalau kita sudah curhat, udah doa sama Allah sebanyakbanyaknya besok lusa selalu ada jawaban”. Partisipan mengungkapkan bahwa setelah sakit mereka merasa lebih dekat dengan Tuhan. Hubungan yang dilakukan adalah melalui ibadah. Hal ini seperti yang diungkapkan oleh salah seorang partisipan:

"setelah saya tidak dapat melakukan aktifitas seperti biasa lagi, sebagai penggantinya saya suka tadarus dan dzikir...karena sakit saya harus lebih teliti dalam beribadah, kemudian ga cuman merasakan keluhan kalau ber ruku (solat) merasakan keringat ya keringat dingin karena cape yah, ada..ooo..inilah kenikmatan. Saya itu ga pake kesal (aral).. oo...inilah kenikmatan."

Pada tema harapan merupakan sumber kekuatan, sebanyak enam orang partisipan mengungkapkan bahwa yang membuat diri mereka bertahan atau harus kuat adalah 
Aan Nuraeni : Makna Spiritualitas pada Klien dengan Sindrom Koroner Aku

sebuah harapan. Berikut beberapa pernyataan partisipan:

"bapa itu dari kecil sudah biasa berkebun, memelihara ternak..seneng bapa itu dari dulu juga, sekarang begini suka sesek... mudah-mudahan aja sembuh jadi bisa ke kebun lagi".

"sekarang ibu ingin sembuh total, ingin melaksanakan ibadah haji hanya itu hutang ibu sama Allah. Masih, masih gimana ya, tugas ibu masih ada satu lagi itu rukun islam kelima, secara harta ibu mampu, Cuma secara fisik ibu sakit gitu ya, jadi sekarang harapannya pengen sembuh untuk bisa melaksanakan itu".

Pada tema spiritualitas adalah permohonan ampunan (pertobatan), sebanyak empat orang partisipan yaitu partisipan ke-2, 6, 7, dan 9 mengungkapkan bahwa permohonan ampunan atau bertobat merupakan salah satu hikmah sakit yang mereka dapatkan saat ini. Pernyataannya tersebut diungkapkan oleh salah satu partisipan berikut ini:

"sekarang saya introspeksi saja karena sudah begini keadaannya ya saya pasrah, sambil minta ampun sama Allah. Ya Allah dulu banyak sikap saya yang salah, ampuni saya."

Pada tema rasa syukur sebagai sumber kekuatan, partisipan mengungkapkan bahwa mereka tetap bersyukur walaupun merasa sakit. Berikut ungkapan salah satu partisipan: "Saya bersyukur sama Allah gitu masih diberi kesempatan untuk bertobat dulu, coba kalau tidak sakit kemudian tahu tahu saya meninggal."

Kategori yang ketiga yaitu spiritualitas adalah hubungan dengan orang lain. Kategori ini memuat dua buah tema. Tema yang pertama adalah perhatian, cinta, dan kasih sayang dari orang lain, serta keberhasilan keluarga sebagai sumber kekuatan dan kebahagiaan. Dukungan keluarga merupakan sumber kekuatan yang diungkapkan oleh semua partisipan. Dukungan keluarga menurut partisipan antara lain meliputi perhatian dan kasih sayang dari keluarga, nasehat ataupun masukan dari keluarga, serta dapat pula berupa dukungan yang bersifat materil. Beberapa pernyataan partisipan mengenai hal ini adalah:

"dukungan keluarga itu sangat penting sekali...semangat hidup ibu itu anak-anak, dukungan dari keluarga...kemarin juga anakanak bilang udah mamah jangan mikirin apa-apa, ya...itulah yang jadi ibu kuat".

"keluarga, sahabat yang menengok saya, merasa apa ya, merasa punya perhatian sama saya, Alhamdulillah membesarkan hati saya...perhatian dari mereka itu penting. Bentuk apa ya, dorongan moril".

Pada tema kedua yaitu memberikan manfaat bagi sesama sebagai sumber kekuatan dan kebahagiaan. Sumber kekuatan lainnya adalah sumber kekuatan yang timbul dari perasaan berguna atau dapat bermanfaat bagi orang lain walaupun dalam keadaan sakit. Berikut pernyataan partisipan mengenai hal tersebut:

"untuk terus kuat ya saya juga melakukan hal-hal yang bisa saya lakukan kepada orang banyak yang bisa..ya itu mungkin yang membantu membuat kita berguna... walaupun sedikit gitu ya kita usahakan untuk memberikan kehidupan".

"ya di dekat rumah ibu kan ada orang tua yang sudah tua, sama anak-anaknya tidak diurus, sangat mengkhawatirkan, sama ibu suka diberi makanan setiap hari...yaa bisa memperhatikan sesama seperti itu bisa membuat ibu bahagia...".

Kategori yang keempat yaitu spiritualitas adalah hubungan dengan lingkungan atau alam. Kategori ini memuat satu buah tema yaitu menyalurkan hobi atau aktivitas di alam sebagai sumber kebahagiaan. Kebahagiaan dan ketenangan batin merupakan salah satu indikatordari spiritualitasitaswell being. Salah satu sumber ketenangan dan kebahagiaan yang diungkapkan oleh partisipan dalam penelitian ini diantaranya adalah menikmati keindahan alam dan beraktivitas di dalamnya. Di bawah ini pernyataan partisipan mengenai hal tersebut:

"yang membuat bapa bahagia biasanya kegiatan kalo sebelum ngajar berangkat ke sawah, sore-sore berangkat ke sawah, kalo sekarang tidak neng, iyah. Ya gitu agak sedih....Pekerjaan bapa walaupun sibuk, tapi ke sawah itu menjadi hiburan gitu. Ketenangan batin bapa".

“...dengan pemandangan alam, ngurus kebon, ngurus kolam itu memang cita-cita saya, karena saya senang dengan alam gitu loh. Namanya juga perhutani seneng dengan yang ijo-ijo". 
Aan Nuraeni : Makna Spiritualitas pada Klien dengan Sindrom Koroner Aku

\section{Pembahasan}

Tema yang muncul dalam penelitian ini terdiri dari empat kategori, yaitu: spiritualitas adalah hubungan dengan diri sendiri, spiritualitas adalah hubungan dengan Tuhan, spiritualitas adalah hubungan dengan orang lain, dan spiritualitas adalah hubungan dengan alam.

Kategori pertama yang muncul yaitu spiritualitas adalah hubungan dengan diri sendiri. Sindrom koroner akut merupakan penyakit berat yang dapat mengakibatkan kematian pada pasien secara mendadak maupun komplikasi yang dapat menjadi berat pada seseorang yang mengalaminya. Keadaan ini akan menimbulkan stres pada penderitanya. Namun demikian, penyakit yang berat (serious illness) dapat menjadi sarana atau kesempatan untuk mendapatkan pendewasaan bagi pasien yang merasakannya dengan cara menegosiasikan konflik dengan diri sendiri dan mengubah pandangan negatif terhadap suatu krisis ke dalam pandangan yang lebih positif (Chao, Chen, \& Yen, 2002; Walton, 2002).

Hasil wawancara terhadap partisipan juga terungkap bahwa pada saat serangan awal terjadi, mereka merasakan ketakutan akan kematian. Hal ini terjadi disebabkan karena keluhan subjektif yang dirasakan pasien pada saat mengalami serangan, berupa rasa nyeri hebat pada dada yang dapat menjalar ke daerah substernal, leher, rahang, lengan kiri, atau ke punggung, ataupun rasa sesak yang tidak tertahankan. Partisipan juga mengungkapkan merasa sedih, frustasi atau pun marah pada Tuhan setelah mengetahui dirinya menderita penyakit ini. Namun demikian, saat ini mereka menyatakan telah menerima penyakit ini dan memaknainya sebagai teguran ataupun cobaan dari Tuhan.

Cobaan atau teguran melalui sakit ini menurut partisipan adalah bukti kecintaan dan kasih sayang Tuhan terhadap dirinya. Partisipan juga mempersepsikan bahwa sakit yang mereka alami merupakan cobaan atau teguran sebagai manifestasi dari rasa kasih sayang Tuhan. Hal ini merupakan pernyataan positif atau disebut juga positive religious coping. Menurut Greenstreet (2006), hal ini mengindikasikan bahwa kualitas hidup seseorang dalam dimensi spiritualitasitas atau dengan kata lain, hal ini mengindikasikan kesehatan spiritualitasitas (spiritualitasitas health) seseorang.

Menurut Walton (2002), hal tersebut dapat dicapai seseorang dengan melawati proses yang sangat dinamis sehingga pada akhirnya menemukan keseimbangan (balance). Pada awalnya, partisipan mempersepsikan sakit sebagai beban, kemudian terjadi perjuangan spiritualitasitas dimana partisipan mengkaji serta menimbang kebaikan dan keburukan dari penyakit yang diderita dengan melibatkan proses refleksi dan introspeksi secara terus menerus dan pada akhirnya partisipan dapat mengganti situasi yang dihadapi dengan cara mengubah pandangan, dari pandangan negatif ke pandangan positif yaitu mengubah persepsi buruk tentang penderitaan yang dihadapi dengan persepsi yang lebih baik. Muncullah tema bahwa partisipan merasa hidupnya menjadi lebih baik saat ini.

Kategori yang kedua yaitu spiritualitas adalah hubungan dengan Tuhan. Sebagian besar dari masyarakat Indonesia merupakan masyarakat religius dan yakin akan adanya Tuhan. Agama di negara Indonesia memegang peranan penting dalam kehidupan masyarakat, begitu pula dengan makna spiritualitasitas yang tergali dalam penelitian ini.

Kepasrahan kepada Tuhan ini merupakan salah satu sumber kekuatan. Menurut MingShium (2006), spiritualitasitas sebenarnya adalah bentuk filosofi sikap hidup seseorang dan sistem nilai yang berasal dari budaya, pendidikan, dan pengalaman pribadi individu. Tema yang muncul pada kategori ini yang pertama adalah kepasrahan kepada Tuhan. Hal ini tidak terlepas dari budaya religius partisipan yang sebagian besar beragama Islam. Sesuai dengan pendapat Ming-Shin (2006), pernyataan tentang kepasrahan oleh partisipan tersebut tidak terlepas dari nilainilai yang ada di dalam Al-qur'an.

Partisipan mengungkapkan telah pasrah karena yakin dengan pertolongan dari Allah. Menurut pandangan Islam, satu-satunya penolong bagi setiap manusia adalah Allah. Kepasrahan yang dimaksud partisipan ini adalah tawakal. Tawakal adalah perbuatan lahir dan batin menyerahkan segala perkara, ikhtiar dan usaha kepada Allah SWT serta berserah diri sepenuhnya untuk mendapatkan manfaat atau menolak madharat (keburukan) 
Aan Nuraeni : Makna Spiritualitas pada Klien dengan Sindrom Koroner Aku

(Supriyanto, 2010).

Menurut ajaran Islam maupun Kristiani, konsekuensi dari kepasrahan pada Tuhan dapat memberikan ketenangan dalam jiwa atau hati setiap manusia. Hal ini diperkuat oleh Joshi, Kumari, dan Jain (2008) dalam penelitiannya yang menyatakan bahwa sikap keagamaan seperti ibadah dan kepasrahan atau tawakal akan memundulkan harapan dan pandangan positif terhadap kehidupan, serta memberikan ketenangan kepada jiwa manusia berupa berkurangnya rasa tertekan atau depresi dalam jiwa manusia.

Ibadah atau komunikasi dengan Tuhan merupakan sumber kekuatan. Hal ini merupakan salah satu tema yang dihasilkan pada kategori kedua. Menurut Hamid (2000), dalam kondisi sakit akan meningkatkan keinginan dan keyakinan spiritualitasitas dari seseorang untuk melakukan sembahyang dan berdoa. Partisipan juga mengungkapkan bahwa sakit yang dialami mendorong mereka untuk lebih dekat dengan Tuhan dan lebih banyak beribadah.

Guillory, dkk. (1997) menyebutkan bahwa spiritualitasitas adalah keyakinan terhadap Tuhan. Hal ini diperlihatkan melalui berbagai aktivitas keagamaan yang dilakukan partisipan. Setelah mengalami situasi krisis, beberapa partisipan juga mengungkapkan bahwa intensitas keagamaannya semakin meningkat. Menurut hasil penelitiannya pula, beberapa partisipan percaya bahwa Tuhan yang memberikan kesembuhan (healing).

Partisipan juga mengungkapkan bahwa harapan merupakan sumber kekuatan. Selalu ada harapan dalam setiap keadaan krisis bahkan kematian sekalipun (Chao dkk., 2002). Dalam penelitian lain juga disebutkan bahwa harapan dan penemuan makna dari krisis yang dialami dapat menjadi kekuatan untuk meneruskan kehidupan bahkan untuk tetap aktif didalamnya (Mok, Wong, \& wong, 2009).

Harapan ini dapat muncul apabila mereka mendapatkan cinta dan hubungan yang harmonis terutama dari orang terdekat seperti keluarga. Disebutkan pula bahwa keluarga merupakan sumber kekuatan terbesar yang dimiliki oleh partisipan. Menurut Nabolsi dan Carson (2011) harapan dan penerimaan mereka terhadap sakit atau penderitaan yang dialami sangat membantu dalam menemukan makna dan tujuan hidup yang sebenarnya.

Partisipan juga mempersepsikan bahwa spiritualitas adalah permohonan ampunan (pertobatan). Permohonan ampunan atau pertobatan dapat memberikan kekuatan pada setiap orang dalam menghadapi kematian. Uraian tersebut diatas menyatakan bahwa seseorang siap menghadapi kematian karena merasa dekat dengan Tuhan dan tidak memiliki dosa yang dibenci oleh Tuhan, dan yakin bahwa mereka akan kembali ke tempat yang lebih baik. Pertaubatan ini pada akhirnya akan menguatkan partisipan dalam menghadapi tantangan yang akan terjadi seperti kematian dan komplikasi akibat sakit yang dialami. Sebagian partisipan menyatakan bahwa mereka telah pasrah dan siap dengan kematian.

Rasa syukur pun menjadi sumber kekuatan bagi partisipan. Menurut Chao, dkk. (2002) menyebutkan bahwa spiritualitasitas adalah bersyukur karena telah mendapatkan karunia. Setiap orang telah diberikan berbagai karunia seperti makanan, kesehatan dan apapun oleh tuhan untuk kehidupannya dan atas dasar itulah manusia harus tetap bersyukur walaupun dalam keadaan menderita.

Salah seorang partisipan menyatakan bahwa dirinya telah mendapatkan berbagai kenikmatan selama hidupnya diantaranya adalah nikmat sehat yang dirasakan jauh lebih lama dibandingkan dengan sakitnya saat ini, sehingga dia masih tetap dapat bersyukur atas nikmat yang telah didapatkan, bahkan dalam keadaan sakit pun rasa syukur itu masih tetap ada terutama bila melihat masih ada orang yang lebih menderita dibanding dirinya saat ini.

Spiritualitas adalah hubungan dengan orang lain. Hal ini merupakan kategori ketiga yang didapatkan dari penelitian ini. Tema pertama pada kategori ini, yaitu perhatian, cinta, dan kasih sayang dari orang lain, serta keberhasilan keluarga sebagai sumber kekuatan dan kebahagiaan. Menurut Wills dalam Taylor dkk. (2004) hal ini didefinisikan sebagai dukungan sosial yaitu persepsi atau pengalaman seseorang bahwa dia dicintai dan diperhatikan, berharga dan dihargai dan diakui sebagai bagian dari jaringan sosial.

Berbagai penelitian tentang stres dan koping memperlihatkan bahwa salah satu bentuk koping yang paling efektif adalah 
Aan Nuraeni : Makna Spiritualitas pada Klien dengan Sindrom Koroner Aku

melalui dukungan sosial. Berbagai bukti menunjukkan terdapat pengaruh yang positif dari dukungan sosial terhadap kesehatan fisik dan mental seseorang (Sheeman \& Thoits dalam Taylor dkk, 2004). Penelitian menunjukkan bahwa cinta, perhatian dari anggota keluarga, maupun orang lain disekitar partisipan membuat partisipan merasa lebih berarti dan dihargai. Perasaan dihargai merupakan sumber kekuatan internal yang sangat besar bagi klien (Mok dkk., 2009).

Dalam adat ketimuran dirasakan bahwa hubungan sosial merupakan hal yang sangat penting. Pernyataan ini didukung oleh penelitian yang dilakukan oleh Markus dan Kitayama (1991), Sweder dan Bourne (1984) serta Triandis (1989) dalam Taylor (2004) bahwa dukungan sosial berpengaruh terhadap koping yang dilakukan pada masyarakat Asia karena keterikatan sosial yang besar diantara mereka.

Tema berikutnya dari kategori ketiga ini yaitu memberikan manfaat bagi sesama sebagai sumber kekuatan dan kebahagiaan. Walton (2002) mengungkapkan bahwa dalam proses untuk mendapatkan kesehatannya kembali, partisipan juga merasa sangat rentan dan bergantung pada orang lain, dan pada saat rasa sehat itu telah didapatkan, partisipan merasa ingin memberikan kembali kepada orang yang membutuhkan. Keinginan untuk dapat memberi atau berguna bagi orang lain yang membutuhkan merupakan bagian yang kuat dalam spiritualitasitas.

Salah satu etos atau watak hidup yang melekat pada masyarakat atau budaya Sunda dalam menjalani kehidupanya adalah harus bageur atau harus berbuat baik. Nilainilai kebudayaan ini juga memungkinkan partisipan yang sebagian besar merupakan masyarakat Sunda merasa bahwa memberi manfaat kepada sesama sudah merupakan sesuatu hal yang lumrah dan harus dilakukan dalam keseharian mereka. Hal ini bila dapat dilakukan tentunya akan menambah kepuasan dan kepercayaan diri mereka.

Kategori keempat dari penelitian ini yaitu spiritualitas adalah hubungan dengan alam. Salah satu tema dalam penelitian ini yaitu menyalurkan hobi atau aktivitas di alam sebagai sumber kebahagiaan. Menurut pandangan Theodore de Bary, Chan dan
Watson (1984) dalam Chao, dkk. (2002) menyatakan bahwa makna spiritualitas salah satunya adalah alam. Hakikat dari surga berjalan melalui alam fisik, dan setiap manusia yang hidup dengan melihat keindahan alam akan mendapatkan ketenangan jiwa dan dapat dikatakan juga sebagai sumber kebahagiaan.

Keindahan merupakan sumber ketenangan bagi manusia dan alam sebagai objek yang dapat memberikan keindahan tersebut. Alam raya ciptaan Tuhan merupakan karya seni yang paling agung dan memesona karena alam merupakan sumber keindahan yang luar biasa. Ketika melihat alam, maka akan menimbulkan imajinasi dan suasana damai serta tentram.

\section{Simpulan}

Penelitian ini mengungkap bahwa pada awalnya partisipan mempersepsikan bahwa sakit yang dialaminya sebagai beban, frustasi, bahkan sampai menimbulkan ketakutan akan kematian. Partisipan juga ternyata mampu mengubah pandangan negatif tentang sakit yang dialaminya kedalam pandangan yang lebih positif, yakni menerima dan siap dengan tantangan yang akan dihadapi. Proses ini terkait dengan Hal ini terjadi karena proses introspeksi diri dan refleksi positif yang terus dilakukan dan didapatkan baik, keterhubungan dengan diri sendiri, Tuhan, orang lain, bahkan alam sekitar.

Hasil penelitian ini mengarahkan institusi pendidikan untuk mampu mempersiapkan perawat yang peka terhadap kebutuhan spiritualitasitas klien yang akan dirawatnya serta diperlukannya penelitian lebih lanjut dan lebih dalam mengenai perawatan spiritualitas pasien.

\section{Daftar Pustaka}

Burkhardt, M. A., \& Nagai-Jacobson, M. G. (2005). Spirituality and health in holistic nursing a handbook for practice (4th ed.). Massachussetts: Jones And Bartlett Publisher. Chao, C. S., Chen, C. H., \& Yen, M. (2002). The essence of spiritualitasitasity of terminally ill patients. Journal of Nursing 
Aan Nuraeni : Makna Spiritualitas pada Klien dengan Sindrom Koroner Aku

Research, 10(4), 237-245.

Departemen Kesehatan. (2009). Profil kesehatan Indonesia 2008. Diakses dari http:// www.depkes.go.id/downloads/publikasi/ Profil $\% 20$ Kesehatan $\% 20$ Indonesia $\% 20$ 2008.pdf.

Greenstreet, W. (2006). Spiritual wellbeing and spiritualitasitas distres. In integrating spiritualitasitasity in health and social care perspective and practical approaches. Seattle: Radcliffe Publishing.

Hancock, B. (2002). Trent focus for research and development in primary health care. Qualitative research journal, 1-31

Lorentz, M. M. (2006). Stress and psychoneuroimmunology revisited: Using mind-body interventions to reduce stres. Alternative Journal of Nursing, 11, 1-11.

Merz, C., Bairey, N., Dwyer, J., Nordstrom, C., Walton, K., Salerno, J., \& Schneider, R. H. (2002). Psychosocial stress and cardiovascular disease: Pathophysiology. Behaviour medical, 27(4), 141-147.

Mok, E., Wong, F., \& Wong, D. (2009). The meaning of spiritualitasitasity and spiritualitasitas care among the Hongkong Chinese terminally ill. Journal of Advanced Nursing, 360-370.

Puchalski.(2001). The role of spiritualitasitasity in health care. Baylor University Medical Center Proceedings, 14(4), 352-357.

Puchalski, C., Virani, R., Otis-Green, S., Baird, P., Bull, J., Chochinov, H., ... Sulmasy, D. (2009). Improving the quality of spiritualitasitas care as a dimension of palliative care: The report of the consensus conference. Journal of Palliative Medicine, 12(10), 885-904.

Scott, E. (2007). Spirituality and mental health: Benefits of spiritualitasitasity. Diakses dari http://stres.about.com/od/optimismspirit ualitasitasity/a/22307_God_power.htm

Taylor, S. E., Sherman, D. K., Kim, H. S., Jarcho, J., Takagi, K., \& Dunagan, M. S. (2004). Culture and social support: Who seeks it and why?. Journal of Personality and Social Psychology, 87(3), 354-362. doi: 10. 1037/0022-3514.87.3.354

Walton, J. (2002). Finding a balance: a grounded theory study of spiritualitasitasity in hemodialysis patients. Nephrology Nursing Journal, 29(5), 447-457.

World Health Organization. (2011). Global Atlas on Cardiovascular Disease Prevention and Control. Diakses dari http://www.who. int/cardiovascular_diseases/en/

Zachariae, R. (2009). Psychoneuroimmunology: A bio-psycho-social approach to health and disease. Scandinavian Journal of Psychology, 50, 645-651. 